\title{
A1 milk and beta-casomorphin-7
}

\author{
Seval ANDİÇ', Rozelin Münevver AYAZ², Şehriban OĞUZ1
}

Cite this article as:

Andiç, S., Ayaz, R.M., Oğuz, Ş. (2021). A1 milk and beta-casomorphin-7. Food and Health, 7(2), 128-137. https://doi.org/10.3153/FH21007

${ }^{1}$ University of Van Yüzüncü Y1l, Department of Food Engineering, Van, Turkey

${ }^{2}$ University of Van Yüzüncü Y11, Institute of Natural and Applied Sciences, Van, Turkey

ORCID IDs of the authors: S.A. $0000-0002-8306-0222$ R.M.A. 0000-0002-8818-9850 Ş.O. 0000-0001-6889-9487

Submitted: 25.05 .2020

Revision requested: 14.08 .2020 Last revision received: 03.10 .2020 Accepted: 04.10.2020

Published online: 09.03.2021

Correspondence: Seval ANDİÇ E-mail: sevalandic@yyu.edu.tr

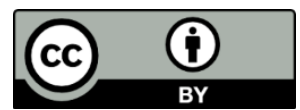

(c) 2021 The Author(s)

\section{ABSTRACT}

Milk is composed of water, proteins, lipids, lactose, vitamins, and minerals. More than $80 \%$ of most mammals' milk proteins are constituted by caseins. Casein is a group of proteins and they are sub-divided into $\alpha \mathrm{s} 1-, \alpha \mathrm{s} 2-, \beta$ - and $\kappa$-casein families. Among these casein families, $\beta$-casein is the second most abundant protein. Different mutations in the cow milk $\beta$-casein gene led to 12 genetic variants and most common of these are genetic variants $\mathrm{A} 1$ and $\mathrm{A} 2$. The $\mathrm{A} 1$ and $\mathrm{A} 2$ variants differ only at amino acid position 67, which is histidine in A1 or proline in A2 milk. This difference in amino acid sequence suggests a conformational change in the secondary structure of the expressed $\beta$-casein. Milk that contains A1 $\beta$-casein and A2 $\beta$-casein are known as A1 milk and A2 milk, respectively. A1 $\beta$-casein milk releases an amino acid bioactive peptide called beta-casomorphin-7 ( $\beta C M-7)$ in small intestine. Beta-casomorphin-7 released from A1 $\beta$-casein is responsible for many human disorders like type-1 diabetes, autism, schizophrenia, alzheimer's disease (AD), attention deficit hyperactivity disorder $(A D H D)$, multiple sclerosis (MS) and heart diseases.

Keywords: A1 Milk, A2 milk, $\beta C M-7$, Casein, Health 


\section{Introduction}

Milk is a liquid secreted from the mammary glands of female mammals following birth for the purpose of feeding the offspring. Since it is secreted with the purpose of feeding it which after the birth is incapable of consuming any other type of food- the milk contains almost all the nutritional elements required to nourish the offspring. The milk, therefore, is a rare type of food which has the potential to contain all the nutrients necessary for life, and which the newborn offspring can consume easily (Fox et al, 2015). Although the amount of milk is very limited in humans and is secreted only in sufficient quantities for the baby, in animals it is usually secreted in higher amounts than needed by the offspring. This makes it possible to use some of the animal milk for the feeding purposes of the humankind. Furthermore, genetic studies have made certain animals capable of yielding significantly higher amounts of milk than they normally do (Patton, 2017).

While milk shows differences in composition based on the mammal species it is secreted from, its primary components are always proteins, fats, and carbohydrates. The ratio of these components changes based on the needs of the offspring of the specific mammal species it was secreted for. Milk further contains other minor components like minerals, vitamins, and enzymes. When naming it, milk is called by the name of the animal it was secreted from (Fox et al, 2017).

Milk proteins, milk fat, and lactose -which is the only carbohydrate in the milk- all hold a significant place in terms of nutrition and of the health of the consumer, and for the technological processing of the milk. Milk proteins are divided into two main parts as casein and serum proteins. A significant proportion of milk proteins are made up of caseins. Milks with casein that makes up for more than $2 / 3$ of its total proteins are called the "casein milks", whereas milks that contain other serum proteins in similar amounts with the casein are called the "albumin milks". Milks of cows, sheep, goat, and buffalo are casein milks, while human, mare, donkey milks are albumin milks. Milks sold in markets and the majority of the dairy products that have technologically been processed are obtained from casein milks. Neither casein nor other serum proteins are of a single type of protein structure. Serum proteins are albumin, globulin, and protease-peptones. Casein, is composed of $\alpha$ s-casein, $\beta$-casein, $\kappa$-casein and $\gamma$ casein fractions (Mehta, 2015).

Proteins are the smallest component blocks of the body, in addition to their important roles of formation and repair of the tissues, undertaking the transportation and storage of various substances, and taking part in in the immune system functions. In the food, proteins are important elements which determine the nutritional value, textural and organoleptic pro- perties of the food. Due to containing all the essential aminoacids, milk proteins are considered to be "total proteins" in terms of their nutritional properties (Damodaran, 1996). Proteins are also a very important source for bioactive peptides. Bioactive peptides are usually protein breakdown products with a short-chain structure containing 2 to 50 amino acids. Although they are present in many different foods like milk, eggs, beans, fish, and corn, milk proteins represent the most important source of bioactive peptides (Park and Nam, 2015). Bioactive peptides found in inactive form are created during the digestion of milk by the digestive system enzymes, during the fermentation of milk by proteolytic starter cultures, or through enzymes derived from microorganisms or plants. Milk-derived bioactive peptides have different physiological bioactivities and properties, like their antihypertension, antimicrobial, antioxidant, antithrombotic, immunomodulator, mineral binding, and opioid effects (Nongonierma and FitzGerald, 2015; Mohanty et al, 2016). However, studies have shown that beta-casomorphin 7 ( $\beta C M-7)$, which is a bioactive peptide and forms as a result of the breakdown of beta-casein, has multiple negative effects on health.

\section{$\beta$-Casomorphin7 ( $\beta \mathrm{CM}-7$ )}

Approximately $82 \%$ of cow's milk proteins consist of caseins and $30-35 \%$ of the casein consists of $\beta$-caseins. So far, $12 \beta-$ casein genetic variant has been identified. These are the A1, A2, A3, B, C, D, E, F, H1, H2, I and G variants. Amongst these, $\mathrm{A} 1, \mathrm{~A} 2, \mathrm{~A} 3$, and $\mathrm{C}$ are commonly encountered in dairy cattle, and the most common are $\mathrm{A} 1$ and $\mathrm{A} 2$ variants. Whether a cow will have $\mathrm{A} 1$ and/or $\mathrm{A} 2$ variant is determined by a couple of genes located in the $6^{\text {th }}$ chromosome. This particular gene has 2 alleles, known as A1 and A2 $\beta$-casein alleles. Research has shown that each cow carries two copies of $\beta$-casein genes. It is possible for a cow to have any one of the A1A1 (homozygote), A2A2 (homozygote), or A1A2 (heterozygote) alleles. In case the animal has the A1A2 alleles, none of these alleles are dominant over the other, and the milk contains equal amounts of A1 and A2 $\beta$-casein. For this reason, a cow with A1A2 produces equal amounts of A1 and A2 $\beta$-casein, while a cow with A2A2 genes produces the A2 $\beta$ casein alone and a cow with A1A1 genes produce only the A1 $\beta$-casein (Priyadarshini et al, 2018). Whether the casein is $\mathrm{A} 1$ or $\mathrm{A} 2$ is based on a small variation in the amino-acid sequence. The $67^{\text {th }}$ amino acid is histidine in A1 $\beta$-casein, whereas it is proline in A2 $\beta$-casein. The peptide bond between the $66^{\text {th }}$ and $67^{\text {th }}$ amino acids in A1 $\beta$-casein, which are isoleucine and histidine, can be broken down by elastase, whereas the same bond for the A2 $\beta$-casein (between the isoleucine and proline in this case) can't be broken down by elastase (Figure 1). Such a breaking down of this bond for the A1 
$\beta$-casein results in the formation of $\beta$-casomorphin 7 ( $\beta C M$ 7 ), whereas it results in the formation of $\beta$-casomorphin 9 $(\beta C M-9)$ for the A2 $\beta$-casein. Considering this, milks that contain the A1 variant are called A1 milks, and the ones with A2 variant are called the A2 milks (Nguyen et al, 2015).

A1 milk, and therefore the $\beta \mathrm{CM}-7$, has been reported to affect countless opioid receptors in nervous, endocrine, and immune systems potentially, and to represent a risk factor for a variety of important diseases and disorders like cardiovascular diseases, type-1 diabetes, autism, and schizophrenia. A2 milk, on the other hand, represents no such risks (McLachlan, 2001; Kaminski et al, 2007; Chia et al., 2017; Banerjee, 2018 ). There is a predominant $\mathrm{A} 1 \beta$-casein variant (A1/ $\beta$-casein $=0.46-0.71)$ in the milk of red-white (Red Danish, Holstein-Friesian, Ayrshire) and black-and-white cattle breeds found in northern Europe (Buchberger, 1995). As a result of artificial insemination practices between 1970 and 1980 using the American Holstein bulls, the level of the A1 variant in the milk of northern European cattle has declined. The A1 variant level in the central and southern European milks is low as well. This is due to the fact that breeds like the Guernsey which has a low level of $A 1$ variant $(\mathrm{A} 1 / \beta$-casein ratio mostly $<0.25)$ and Jersey Simmental Swiss Brown which almost doesn't have any A1 variant $(\mathrm{A} 1 / \beta$-casein $=0.01)$ are the predominant races in the region (Zikakis et al, 1974). The results of the studies performed to this date have shown that milks from Northern European cattle breeds such as the Friesian, Ayrshire, British Shorthorn and Holstein breeds contain
A1 $\beta$-casein, while milk from Channel Island cattle, Guernsey, Jersey, southern France domestic cattle, Charolais - Limousin, African original Zebu cattle, and Gir, Tharparkar, Rathi, Red Sindhi, Sahiwal, Kankrej and Hariana dairy cattle of India contain A2 $\beta$-casein. Milks from African and Asian pure indigenous breeds contain only A2 $\beta$-casein and is called the "safe milk" (Laugesen and Elliott, 2003; Boro et al, 2016).

$\beta \mathrm{CM}-7$ is a biomodulator substance, and is considered as an exorphine. $\beta C M-7$ is a $\mu$-Opioid receptor antagonist that is capable of entering the blood circulation through the digestive system. Its amount in the circulation increases with the amount of the consumed milk. Human milk especially colostrum contains this exorphine as well, but its activity in human milk is lower compared to the cow milks. Also human milk $\beta$-casein structure is the closer to cow A2 milk $\beta$-casein structure than cow A1 milk $\beta$-casein (Jarmołowska et al, 2007; U1 Haq et al, 2014a; Chia et al, 2017; Priyadarshini et al, 2018) (Figure 2). $\beta \mathrm{CM}-7$ has also been detected in the blood of pregnant and breastfeeding women, but it hasn't been determined in males and in non-pregnant women. Accordingly, $\beta C M-7$ has also been emphasized to potentially have a physiological significance for pregnancy and for birth (Jaiswal et al, 2014). The $4^{\text {th }}$ and $5^{\text {th }}$ position amino acids of $\beta C M-7$ of cow and human milk are different from each other. Due to this structural difference, the opioid effects of $\beta \mathrm{CM}-7$ originating from these two sources is also different. $\beta \mathrm{CM}-7$ of cow origin has 10 times more opioid effect compared to its human-origin counterpart.

\section{A1 $\beta$-casein protein chain}

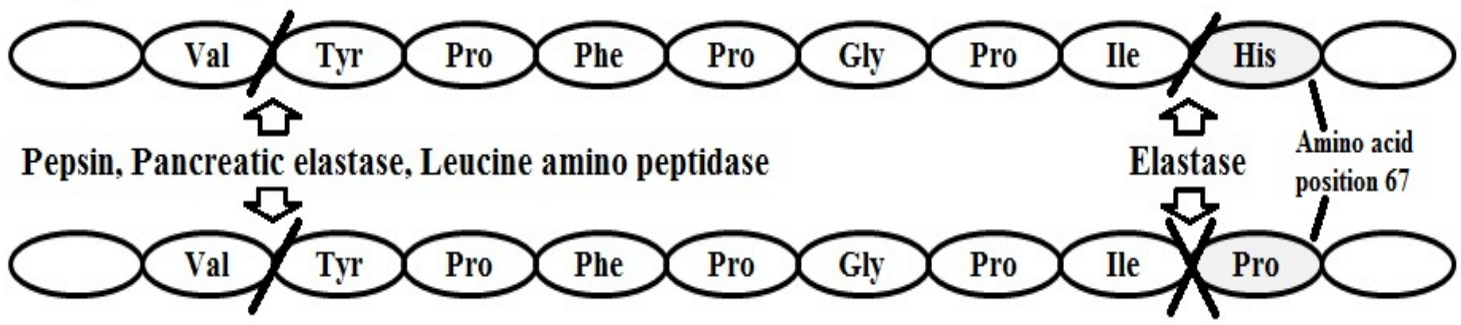

\section{A2 $\beta$-casein protein chain}

Figure 1. Difference between conformational change of A1 $\beta$-casein and A2 $\beta$-casein 
Cow A1 milk $\beta$-casein protein chain
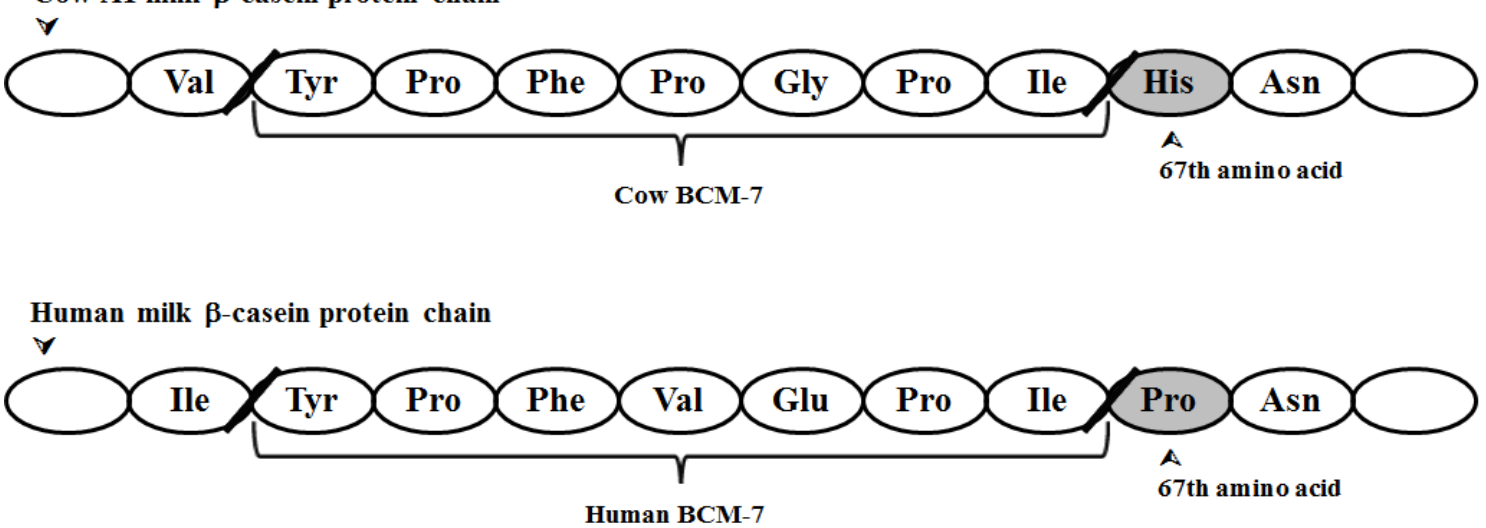

Cow A2 milk $\beta$-casein protein chain

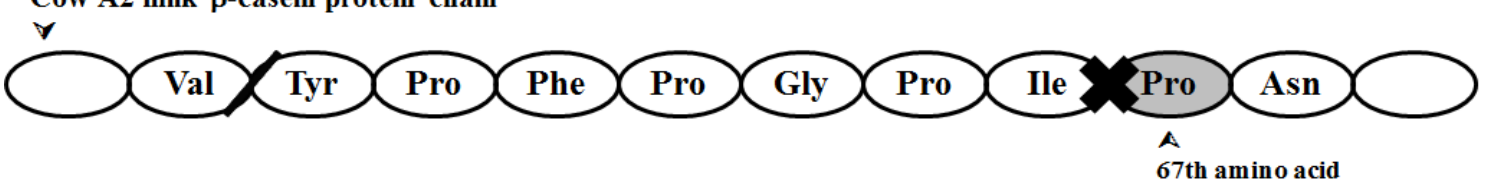

Figure 2. Structure of cow milk A1 and A2 $\beta$-casein, human milk $\beta$-casein, cow $\beta C M-7$ and human $\beta C M-7$

Studies have shown that cow $\beta \mathrm{CM}-7$ may play a neuro-chemical role in establishing the mother-cub connection, and in learning and environmental adaptation processes of calves and young cattle. Accordingly, $\beta \mathrm{CM}-7$ doesn't represent a health risk for the individuals that consume the milk from their own species -on the contrary, it has certain positive roles to play-whereas the $\beta \mathrm{CM}-7$ originating from $\mathrm{A} 1$ dairy milk, in particular, can cause a series of health problems for humans (Jaiswal et al, 2014). $\beta \mathrm{CM}-7$ was determined in whole pasteurized milk, ultra-heat treated milk, bottle-sterilized milk, fermented milks like yoghurt and probiotic fermented milk (Ul Haq et al, 2015). But it is reported that fermentation and storage reduced $\beta \mathrm{CM}-5$ and $\beta \mathrm{CM}-7$ concentration in yoghurt (Nguyen et al, 2014; Nguyen, 2015).

\section{$\beta C M-7$ and Health}

Since they contain all of the essential amino acids in their structure, milk proteins are very important in terms of nutrition for people of all ages. The human being, who starts life mostly by consuming breast milk, also begins to consume milk from various animals and dairy products obtained from these in his childhood and adulthood periods. Consumption of milk proteins was shown to reduce the risk of various diseases like diabetes, muscle atrophy, atherosclerosis, high blood pressure, cardiac diseases, and osteoporosis, and to further have anticarcinogenic, hypocholesterolemic, and ACE (angiotensin-converting enzyme) inhibitory effects through bioactive peptides within the milk (Davoodi et al, 2016; Mohanty et al, 2016; Banerjee, 2018; Lorenzo et al, 2018). That being said, one particular bioactive peptide called $\beta \mathrm{CM}-7$, which is one of the hydrolysis products of casein, can act as a risk factor for various diseases and disorders like type-1 diabetes, ischemic heart disease, autism, schizophrenia, and sudden infant death syndrome (Kadam et al, 2017; Banerjee, 2018).

\section{Type-1 Diabetes}

There are claims that there is a positive correlation between the consumption of A1 milk and the incidence of Type-1 diabetes. The relationship between Type- 1 diabetes and A1 milk consumption is explained by several theories. According to the first of such theories, $\beta C M-7$ suppresses the immune system of the individual and increases the vitality of enteroviruses, endogenous retroviruses and/or pathogens bacteria such as Mycobacterium avium which then damage the pancreatic $\beta$-cells. Increased vitality of these types of pathogens is related to the triggering of symptoms akin to type-1 diabetes in the individual (Kaminski et al, 2007; Parashar and Saini, 2015; Chia et al, 2018). Another theory holds that certain peptides that are hydrolysates of $\beta$-casein mimic the structure of GLUT-2 protein, which is normally tasked with the transportation of the glucose. Sensing these 
peptides as antigens, the T-cells activate the beta cells to produce antibodies against them. In the end, these antibodies destroy not only the $\beta$-casein variants but also the beta cells that produce the insulin, resulting in type-1 diabetes (Parashar and Saini, 2015).

Epidemiologic studies related to the subject have shown strong positive correlations between type- 1 diabetes and A1 milk consumption. In a 15 -year study that covered 19 countries -including Finland, Austria, Iceland, Denmark, and France- a very strong correlation between the proteins originating from A1 milk (with the exclusion of cheese) and occurrence of type-1 diabetes was revealed $(r=0.92$, $\mathrm{p}<0.00001)$. The same study reports that A1 milk consumption for the periods of $0-4,5-9$, and 10-14 years and incidence rate of type- 1 diabetes as $r=0.80,0.81$, and 0.81 respectively, which are quite similar to each other. The study has reported the correlation between the type- 1 diabetes occurrence and consumption of $\mathrm{A} 2, \mathrm{~B}$, and $\mathrm{C}$ variants of casein was insignificant. It was also revealed by that particular study that occurrence of type-1 diabetes was higher in countries like Finland and Sweden where A1 consumption per individual was high, whereas it was lower in countries like Japan and Venezuela where A1 $\beta$-casein consumption was low (Laugesen and Elliott, 2003).

The results obtained from animal experiments also show meaningful relationships between A1 $\beta$-casein consumption and type- 1 diabetes incidence. In a study performed on nonobese diabetic mice, none of the mice fed with A2 $\beta$-casein diet developed auto-immune diabetes, whereas $47 \%$ of the mice fed with A1 $\beta$-casein diet developed auto-immune diabetes (Elliott et al, 1997). Another study has shown that 50\% of the rats fed with a standard laboratory feed developed autoimmune diabetes, while this ratio dropped to $15 \%$ in rats which were fed with a semi-synthetic diet. Introducing milk to the semi-synthetic diet, however, has increased the ratio back to 52\% (Elliott and Martin, 1984).

Knip et al. (2014) reported that being fed with mixed diet proteins increases the type-1 diabetes risk for children that are genetically predisposed. Beta-cell autoimmunity emerges in the early periods of life, and the diets consumed in these periods may alter the type- 1 diabetes risk. Case assessment studies on the subject have shown that the consumption of cow milk from early periods of childhood is a risk factor for type-1 diabetes (Gimeno and de Souza, 1997; Virtanen et al, 2014). For infants, consumption of cow milk before 2 months of age has been reported to be a more influential environmental factor for type- 1 diabetes, compared to milk consumption after 4 months (Knip et al, 2010a). A study performed in Finland has shown, based on the data obtained from a total of
690 children with type- 1 diabetes and less than 15 years of age, that consumption of cow milk proteins before 2 months of age increased type-1 diabetes risk by twofold (Virtanen et al, 1993). Some researchers report that cow milk proteins increase the type-1 diabetes risk in genetically predisposed children (Knip et al, 2010b; Chia et al, 2017) while others have reported that cow milk is a risk factor for type-1 diabetes regardless of genetical predisposition (Lamb et al, 2015).

\section{Ischemic Heart Disease}

Epidemiological studies have shown that consumption of $\beta$ casein A1 has a strong relationship with ischemic heart disease. Despite consuming animal milk in great amounts, Masai communities of East Africa and Samburu communities of Northern Kenya have little to no incidence of heart disease. This is because these communities obtain their milk from the zebu cattle, which carry the A2 alleles (McLachlan, 2001). In a study performed covering a total of 17 countries, the amount of A1 milk consumption in 1980 and the incidences of death caused by cardiovascular diseases in the years of 1985 and 1990 was found to have a strong correlation. In another study performed regarding the cow milk and ischemic heart diseases, the correlation between the A1 $\beta$-casein amount consumed per individual and the ischemic heart disease was found as $r=0.76$, which is considerably high. The study took into account diseases that have occurred 5 years after the consumption (Laugesen and Elliott, 2003). Similarly, was reported a strong correlation $(\mathrm{r}=0.86)$ between the consumption of A1 $\beta$-casein of milk protein origin (excluding the cheeses) and deaths due to ischemic heart diseases [WHO MONICA (monitoring trends and determinants in cardiovascular disease) project] (McLachlan, 2001).

An animal experiment has seen rabbits fed with diets containing different ratios of casein variants (A1 and A2), serum proteins, and cholesterol. Comparison of diets that didn't include cholesterol in their diets has revealed that diets that contained $\beta$-casein A1 have resulted in higher serum cholesterol, LDL, HDL, and triglyceride levels, compared to the diets that contained $\beta$-casein A2 and serum proteins (Tailford et al, 2003). It has also been reported that total casein consumption (which includes all the sub-fractions of casein obtained from milk through acid precipitation) has promoted the development of atherosclerosis in rabbits, monkeys, and mice (Anthony et al, 1998; Ni et al. 1998) and that $\beta$-casein A1 was atherogenic (Tailford et al, 2003).

Tyrosyl is a protein oxidation product and was determined to be present in the atherosclerotic lesions, and $\beta \mathrm{CM}-7$ is a potential source for the tyrosyl radical (Zeng et al, 2018). Furthermore, $\beta \mathrm{CM}-7$ has physiological effects over the oxidation 
of LDL, and peroxidation of LDL lipid components. These oxidation products, in turn, may cause the development of various heart diseases (Kamiñski et al, 2007).

\section{Autism and Schizophrenia}

Autism is a lifelong neurodevelopmental disorder that often affects social, cognitive, and creative abilities (Shattock and Whiteley, 2002; Crane et al, 2016). Even though certain genes that can cause autism have been identified, it is claimed that genetic and environmental factors both can play a role in the development of the disorder (Shattock and Whiteley, 2002; Abrahams and Geschwind, 2008; Sokolov et al, 2014). The fact that certain milk protein-derived peptides have an opioid effect has led to the development of the hypothesis that a relationship between autism and extreme opioids may exist. According to this hypothesis, genetic disposition and/or environmental stress at early ages can cause changes in the intestinal functions, an increase in the permeability of the intestinal mucosa, and cause a reduction in proteolytic activity. Together with these factors, reduced peptidase activity and increase in blood-brain barrier may result in accumulation of opioid peptides (like casomorphin) in the brain and in the blood, which in turn may result in hyperpeptidemia. In the end, the chronically increasing exorphine levels in the brain may affect the opioid and neurotransmitter systems, causing the emergence of disorders like autism (Shattock and Whiteley, 2002; Sokolov et al, 2014).

According to the data obtained from infants, fed breast milk and baby food containing cow's milk, the highest human $\beta C M-7$ immune-reactive substance concentration was found in the infants fed breast milk, whereas the highest concentration of cow $\beta C M-7$ immune-reactive substances were found in infants fed with baby food containing cow's milk. The babies fed breast milk displayed normal motor and muscular development, whereas the babies fed with baby food containing cow's milk had delayed motor and muscular development (Kost et al, 2009).

Autistic children and their mothers were found to have high amounts of endogenous opioid peptides in their serum, blood cells, and cerebrospinal fluids (Brambilla et al, 1997; Nagamitsu et al, 1997; Leboyer et al, 1999; Tordjman et al, 2009). In a study, the urine of autistic children was found to contain higher $\beta \mathrm{CM}-7$, compared to the urine of healthy children in the control group. The study has reported that the $\beta \mathrm{CM}-7$ presence and the autistic symptoms were correlated, and continuous $\beta C M-7$ consumption in early ages provided a step for autistic disorders, damaging the early development period of the child (Sokolov et al, 2014). Animal experiments have shown that $\beta \mathrm{CM}-7$ may play part in developing behavioral disorders similar to those seen in autism and schizophrenia (Sun and Cade, 1999; Sun et al, 1999).

Schizophrenia and autism are related to hyperpeptemia and hyperpeptidurea, and it has been reported that elimination of the low molecular weight peptides from the blood through hemodialysis, or feeding with diets that don't have milk or gluten, could result in remission of schizophrenic symptoms. Also reports that $90 \%$ of the schizophrenic patients and $86 \%$ of the autistic patients had high $\beta C M-7$ IgG antibodies (Cade et al, 1990).

\section{Sudden Infant Deaths}

Sudden Infant Death Syndrome refers to the death of the infants of 12 months of age and lower, usually in their sleep. Brain anomalies, lower birth weight, respiratory infections, and environmental factors that prevented the baby from breathing can be cited amongst the potential causes of death. It has been claimed that $\beta \mathrm{CM}-7$ is also amongst the causes of death (Mallepalli et al, 2017; Sun et al, 2003). $\beta C M-7$ is quite stable against enzymatic breakdown. Yet, it is the substrate of Dipeptidyl-peptidase IV (DPPIV). After an apnoea event, infants with apnoea were found to have higher levels of $\beta C M-$ 7 and lower levels of DPP4 in their serum compared to those who were healthy. Accordingly, it has been reported that the high concentration of $\beta C M-7$ due to increased DPPIV levels could be responsible for the depression of respiration (Wasilewska et al, 2011). $\beta C M-7$ taken in by the diet can be absorbed through the digestive tract and can pass the bloodbrain barrier due to the central nervous system not being fully developed yet. In babies with abnormal breath control or with vagal nerve development disorders, $\beta \mathrm{CM}-7$ causes depression in the respiration center in the brain, causing death (Sun et al, 2003).

\section{Other Claims Regarding A1 Milk and BCM-7}

A subject being discussed is the calcium/magnesium ratio differences between A1 and A2 milks. A1 milks have calcium to magnesium ratio of $10: 1$, whereas $A 2$ milks have a ratio of $2: 1$. Extended periods of A1 milk consumption may lead to magnesium deficiency and the problems associated with it (Boro et al, 2016).

In some studies, results were obtained related with both inflammatory and immune responses to casomorphins within the gastrointestinal system. In a study where mice were fed orally with $\beta \mathrm{CM}-7$ or $\beta \mathrm{CM}-5$, it is reported that both peptides increased expression of inflammatory markers. The authors reported that $\beta \mathrm{CM}-7$ and $\beta \mathrm{CM}-5$ stimulate inflammatory responses through the T2 pathway (U1 Haq et al, 2014a). U1 Haq 
et al. (2014b), reported similar gastrointestinal immune effects in mice fed a milk-free basal diet supplemented with A1 compared to mice fed a diet supplemented with A2 $\beta$-casein.

Another subject being discussed is the $\beta \mathrm{CM}-7$ and lactose interactions. There are tree mechanisms that affect lactose malabsorption. The first mechanism is that the $\beta C M-7$ affects the activity and production of lactase with its inflammatory characteristics. The second mechanism is that changes in the gut microbiota caused by gut inflammation affects the processing of malabsorbed lactose. The third mechanism is that delayed gastrointestinal transit caused by $\beta \mathrm{CM}-7$ leads to increased lactose fermentation (Pal et al, 2015). In their study using rats, Barnett et al. (2014), have shown that consumption of A1 $\beta$-casein has direct effects on gastrointestinal function and A1 $\beta$-casein diets delay gastrointestinal transit time compared to A2 $\beta$-casein diets.

\section{Conclusions}

$\mathrm{A} 1$ and $\mathrm{A} 2$ milks that contain the A1 and $\mathrm{A} 2$ variants of $\beta$ casein are still discussion topics in terms of public health. Based mostly on epidemiologic and animal-based experiments, A1 milk and the $\beta \mathrm{CM}-7$ are claimed to cause various diseases and disorders like type-1 diabetes, ischemic heart disease, autism, schizophrenia, magnesium deficiency, and sudden infant death syndrome. Data from human clinical trials to back these claims up are limited. That being said, the claims are serious enough, considering the diseases and disorders attributed to A1 milk and $\beta \mathrm{CM}-7$ as potential causes. For this reason, the subject has to be researched with additional expemental studies.

\section{Compliance with Ethical Standard}

Conflict of interests: The authors declare that for this article they have no actual, potential or perceived the conflict of interests.

Ethics committee approval: The authors declare that this study does not require ethical permission.

Funding disclosure: -

Acknowledgments: -

Disclosure: A part of this review was presented as poster and published in abstract form at the 3rd International and 26th National Iranian Food Science and Technology Congress, 17 - 19 Eylül 2019, Tahran, Iran.

\section{References}

Abrahams, B.S., Geschwind, D.H. (2008). Advances in autism genetics: on the thresholdof a new neurobiology. Nature Reviews Genetics, 9(5), 341-55.

https://doi.org/10.1038/nrg2346

Anthony, M.S., Clarkson, T.B., Williams, J.K. (1998). Effects of soy isoflavones on atherosclerosis: potential mechanisms. American Journal of Clinical Nutrition, 68, 13901393.

https://doi.org/10.1093/ajcn/68.6.1390S

Banerjee, S. (2018). A2 Milk: The unknown story about a milk protein. Acta Scientific Nutritional Health, 2(3), 28-31.

Barnett, M. P., McNabb, W. C., Roy, N. C., Woodford, K. B., Clarke, A. J. (2014). Dietary A1 $\beta$-casein affects gastrointestinal transit time, dipeptidyl peptidase- 4 activity, and inflammatory status relative to A2 $\beta$-casein in Wistar rats. International Journal of Food Sciences and Nutrition, 65, 720727.

https://doi.org/10.3109/09637486.2014.898260

Boro, P., Naha, B.C., Saikia, D.P., Prakash, C. (2016). A1 and A2 milk \& its impact on human health. International Journal of Science and Nature, 7(1), 01-05.

Brambilla, F., Guareschi-Cazzullo, A., Tacchini, C., Musetti, C., Panerai, A.E., Sacerdote, P. (1997). Beta endorphin and cholecystokinin-8 concentrations in peripheral bloodmononuclear cells of autistic children. Neuropsychobiology, 35(1), 1-4.

https://doi.org/10.1159/000119322

Buchberger, J. (1995). Genetic polymorphism of milk proteins: Differences between breeds. Bulletin IDF, 304, 5-6.

Cade, R., Wagemaker, H., Privette, R.M., Fregly, M.S., Rogers, J., Orlando, J. (1990). The effect of dialysis and diet on schizophrenia. Psychiatry: A World Perspective, 3, 494500 .

Chia, J. S. J., McRae, J. L., Kukuljan, S., Woodford, K., Elliott, R.B., Swinburn, B., Dwyer, K. M. (2017). A1 betacasein milk protein and other environmental pre-disposing factors for type 1 diabetes. Nutrition \& Diabetes, 1(7), 1-7. https://doi.org/10.1038/nutd.2017.16

Chia, J.S.J., McRae, J.L., Enjapoori, A.K., Lefèvre, C.M., Kukuljan, S., Dwyer, K.M. (2018). Dietary Cows' Milk 
Protein A1 Beta-Casein Increases the Incidence of T1D in NOD Mice. Nutrients, 10(9), 1291.

https://doi.org/10.3390/nu10091291

Crane, L., Chester, J.W., Goddard, L., Henry, L.A., Hill, E. (2016). Experiences of autism diagnosis: A survey of over 1000 parents in the United Kingdom. Autism, 20(2), 153-162. https://doi.org/10.1177/1362361315573636

Damodaran, S. (1996). Amino Acids, peptides, and proteins. In Fennema, O. R. (Ed.), Food Chemistry (p. 321-425). Marcel Dekker, Inc. New York. ISBN: 0849384737, 9780849384738

Davoodi, S. H., Shahbazi, R., Esmaeili, S., Sohrabvandi, S., Mortazavian, A.M., Jazayeri, S., Taslimi, A. (2016). Health-Related Aspects of Milk Proteins. Iranian Journal of Pharmaceutical Research, 15(3), 573-591, 2016.

https://doi.org/10.22037/IJPR.2016.1897

Elliott, R.B., M. Martin, J.M. (1984). Dietary protein: a trigger of insulin-dependent diabetes in the BB rat? Diabetologia, 26(4), 297-299.

https://doi.org/10.1007/BF00283653

Elliott, R.B., Wasmuth, W.H., Bibby, N.J., Hill, J.P. (1997). The role of $\beta$-casein variants in the induction of insulin-dependent diabetes in the non-obese diabetic mouse and humans. Food and Agriculture Organization, Brussels, Belgium, IDF Special Issue, No. 9702, 445-453.

https://doi.org/10.1007/s001250051

Fox, P.F., Uniacke-Lowe, T., McSweeney, P.L.H., O'Mahony, J.A. (2015). Dairy Chemistry and Biochemistry (p. 584). Second Edition, Switzerland: Springer, Cham. ISBN: 978-3-319-14892-2.

https://doi.org/10.1007/978-3-319-14892-2

Fox, P.F., Guinee, T.P., Cogan, T.M., McSweeney, P.L.H. (2017). Fundamentals of cheese science (p. 799). Boston: Springer, US. ISBN: 978-1-4899-7681-9

https://doi.org/10.1007/978-1-4899-7681-9

Gimeno, S.G., de Souza, J.M. (1997). IDDM and milk consumption. A case-control study in Sao Paulo, Brazil. Diabetes Care, 20(8), 1256-1260.

https://doi.org/10.2337/diacare.20.8.1256
Jaiswal, K.P., De, S., Sarsavan, A. (2014). Review on bovine beta-casein (A1, A2) gene polymorphism and their potentially hazardous on human health. International Journal of Environment \& Animal Conservation, 3(1), 1-12.

Jarmołowska, B., Sidor, K., Iwan, M., Bielikowicz, K., Kaczmarski, M., Kostyra, E., Kostyra, H. (2007). Changes of $\beta$-casomorphin content in human milk during Lactation. Peptides, 28, 1982-1986.

https://doi.org/10.1016/j.peptides.2007.08.002

Kadam, B.R., Ambadkar, R.K., Rathod, K.S., Pandiyan, C. (2017). A1/A2 milk and human health: A brief review. Journal of Environment and Bio-Sciences, 31(2), 357-362.

Kamiński, S., Kamiński, A., Kostyra, E. (2007). Polymorphism of bovine beta-casein and its potential effect on human health. Journal of Applied Genetics, 48(3), 189-198.

https://doi.org/10.1007/BF03195213

Knip, M., Virtanen, S.M., Seppa, K., Ilonen, J., Savilahti, E., Vaarala, O., Reunanen, A., Teramo, K., Hämäläinen, A.M., Paronen, J., Dosch, H.M., Hakulinen, T., Akerblom, H.K. (2010a). Dietary intervention in infancy and later signs of beta-cell autoimmunity. New England Journal of Medicine, 363(20), 1900-1908.

https://doi.org/10.1056/NEJMoa1004809

Knip, M., Virtanen, S.M., Akerblom,, H.K. (2010b). Infant feeding and the risk of type 1 diabetes. American Journal of Clinical Nutrition, 91(5), 1506S-1513S.

https://doi.org/10.3945/ajen.2010.28701C

Knip, M., Akerblom, H.K., Becker, D., Dosch, H.M., Dupre, J., Fraser, W., Howard, N., Ilonen, J., Krischer, J.P., Kordonouri, O., Lawson, M.L., Palmer, J.P., Savilahti, E., Vaarala, O., Virtanen, S.M. (2014). Hydrolyzed infant formula and early beta-cell autoimmunity: a randomized clinical trial. Journal of the American Medical Association, 311, 2279-2287.

https://doi.org/10.1001/jama.2014.5610

Kost, N.V., Sokolov, O.Y., Kurasova, O.B., Dmitriev, A.D., Tarakanova, J.N., Gabaeva, M.V., Zolotarev, Y.A., Dadayan, A.K., Grachev, S.A., Korneeva, E.V., Mikheeva, I.G., Zozulya, A.A. (2009). $\beta$-Casomorphins-7 in infants on different type of feeding and different levels of psychomotor development. Peptides, 30, 1854-1860.

https://doi.org/10.1016/j.peptides.2009.06.025 
Lamb, M.M., Miller, M., Seifert, J.A., Frederiksen, B., Kroehl, M., Rewers, M., Norris, J.M. (2015). The effect of childhood cow's milk intake and HLA-DR genotype on risk of islet autoimmunity and type 1 diabetes: The Diabetes Autoimmunity Study in the Young. Pediatr Diabetes, 16(1), 3138 .

https://doi.org/10.1111/pedi.12115

Laugesen, M., Elliott, R.B. (2003). Ischaemic heart disease, type 1 diabetes, and cow milk A1 $\beta$-casein. New Zealand Medical Journal, 116(1168), 1-19.

Leboyer, M., Philippe, A., Bouvard, M., Guilloud-Bataille, M., Bondoux, D., Tabuteau, F., Feingold, J., Mouren-Simeoni, M.C., Launay, J.M. (1999). Whole blood serotonin and plasma beta-endorphin in autistic probandsand their first-degree relatives. Biological Psychiatry, 45(2), 158-163.

https://doi.org/10.1016/S0006-3223(97)00532-5

Lorenzo, J.M., Munekata, P.E.S., Gómez, B., Barba, F.J., Mora, L., Pérez-Santaescolástica, C., Toldrá, F. (2018). Bioactive peptides as natural antioxidants in food products A review. Trends in Food Science \& Technology, 79, 136147.

https://doi.org/10.1016/j.tifs.2018.07.003

Mallepalli, S., Kumar, R.K., Sriram, N. (2017). Difference between A1 and A2 milk: Risk of A1 milk. International Journal of Allied Medical Sciences and Clinical Research, 5(1), 163-167.

McLachlan, C.N. (2001). B-kazein A1, ischaemic heart disease mortality and other illness. Medical Hypotheses, 56(2), 262-267.

https://doi.org/10.1054/mehy.2000.1265

Mehta, B.M (2015). Chemical composition of milk and milk products. In Cheung, P. C. K., Mehta, B. M. (Eds): Handbook of Food Chemistry, (p. 511-553), Berlin: Springer-Verlag. ISBN: 978-3-642-36604-8

https://doi.org/10.1007/978-3-642-36605-5

Mohanty, D.P., Mohapatra, S., Misra, S., Sahu, P.S. (2016). Milk derived bioactive peptides and their impact on human health - A review. Saudi Journal of Biological Sciences, 23(5), 577-583.

https://doi.org/10.1016/j.sjbs.2015.06.005

Nagamitsu, S., Matsuishi, T., Kisa, T., Komori, H., Miyazaki, M., Hashimoto, T., Yamashita, Y., Ohtaki, E., Kato,
H (1997). CSF beta-endorphin levels in patients with infantile autism. Journal of Autism and Developmental Disorder, 27(2), 155-163.

Nguyen, D.D., Solah, V.A., Johnson, S.K., Charrois, J.W. A., Busetti, F. (2014). Analytical Methods Isotope dilution liquid chromatography-tandem mass spectrometryfor simultaneous identification and quantification of beta-casomorphin 5 and beta-casomorphin 7 in yoghurt. Food Chemistry, 146, 345-352.

https://doi.org/10.1016/j.foodchem.2013.09.057

Nguyen, D.D., Johnson, S.K., Busetti, F., Solah, V.A. (2015). Formation and degradation of beta-casomorphins in dairy processing. Critical Reviews in Food Science and Nutrition, 55(14), 1955-1967.

https://doi.org/10.1080/10408398.2012.740102

Ni, W., Tsuda, Y., Sakono, M., Imaizumi, K. (1998). Dietary soy protein isolate, compared with casein, reduces atherosclerotic lesion area in apolipoprotein E-deficient mice. Journal of Nutrition, 128(11), 1884-1889.

https://doi.org/10.1093/jn/128.11.1884

Nongonierma, A.B., FitzGerald, R.J. (2015). The scientific evidence for the role of milk protein-derived bioactive peptides in humans: A Review. Journal of Functional Foods, 17, 640-656.

https://doi.org/10.1016/j.jff.2015.06.021

Pal, S., Woodford, K., Kukuljan, S., Ho, S. (2015). Milk intolerance, beta-casein and lactose. Nutrients, 7(9), 72857297.

https://doi.org/10.3390/nu7095339

Parashar, A., Saini, R.K. (2015). A1 Milk and its controversy-A review. International Journal of Bioassays, 4(12), 4611-4619.

https://doi.org/10.21746/ijbio.2015.12.007

Park, Y.W., Nam, M.S. (2015). Bioactive peptides in milk and dairy products: A Review. Korean Journal for Food Science of Animal Resources, 35(6), 831-840.

https://doi.org/10.5851/kosfa.2015.35.6.831

Patton, S. (2017). Milk: Its remarkable contribution to human health and well-being (p. 276), New York: Routledge. ISBN: 1412805112

https://doi.org/10.4324/9781315124513 
Priyadarshini, P., Mishra, C., Mishra, B., Swain, K., Rout, M., Mishra, S.P. (2018). Impact of milk protein on human health: A1 verses A2. International Journal of Chemical Studies, 6(1), 531-535.

https://doi.org/10.22271/chemi

Shattock, P., Whiteley, P. (2002). Biochemical aspects in autism spectrum disorders: updating the opioid-excess theory and presenting new opportunities for biomedical intervention. Expert Opinion on Therapeutic Targets, 6(2), 175-183. https://doi.org/10.1517/14728222.6.2.175

Sokolov, O., Kost, N., Andreeva, O., Korneeva, E., Meshavkin, V., Tarakanova, Y., Dadayan, A., Zolotarev, Y., Grachev, S., Mikheeva, I., Varlamov, O., Zozulya, A. (2014). Autistic children display elevated urine levels of bovinecasomorphin-7 immunoreactivity. Peptides, 56, 68-71. https://doi.org/10.1016/j.peptides.2014.03.007

Sun, Z., Cade, J.R. (1999). A peptide found in schizophrenia and autism causes behavioral changes in rats. Autism, 3(1), $85-95$.

https://doi.org/10.1177/1362361399003001007

Sun, Z., Cade, J.R., Fregly, M.J., Privette, R.M. (1999). $\beta$-casomorphin induces Fos-like immunoreactivity in discrete brain regions relevant to schizophrenia and autism. Autism, $3(1), 67-83$.

https://doi.org/10.1177/1362361399003001006

Sun, Z., Zhang, Z., Wang, X., Cade, R., Elmer, Z., Fregly, M. (2003). Relation of beta-casomorphin to apnea in sudden infant death syndrome. Peptides, 24, 937-943.

https://doi.org/10.1016/S0196-9781(03)00156-6

Tailford, K.A., Berry, C.L., Thomas, A.C., Campbell, J.H. (2003). A casein variant in cow's milk is atherogenic. Atherosclerosis, 170(1), 13-9.

https://doi.org/10.1016/S0021-9150(03)00131-X

Tordjman, S., Anderson, G.M., Botbol, M., Brailly-Tabard, S., Perez-Diaz, F., Graignic, R., Carlier, M., Schmit, S., Rolland, A.C., Bonnot, O., Trabado, S., Roubertoux, P., Bronsard, G. (2009). Pain reactivity and plasma beta-endorphin in children and adolescents with autistic disorder. PLOS ONE, 4(8), e5289.

https://doi.org/10.1371/journal.pone.0005289

Ul Haq, M.R., Kapila, R., Saliganti, V. (2014a). Consumption of $\beta$-casomorphins-7/5 induce inflammatory immune response in mice gut through Th2 pathway. Journal of Functional Foods, 8(1), 150-160.

https://doi.org/10.1016/j.jff.2014.03.018

UI Haq, M.R., Kapila, R., Sharma, R., Saliganti, V., Kapila, S. (2014b). Comparative evaluation of cow $\beta$-casein variants (A1/A2) consumption on Th2-mediated inflammatory response in mouse gut. European Journal of Nutrition, 53(4), 1039-1049.

https://doi.org/10.1007/s00394-013-0606-7

UI Haq, M.R., Kapila, R., Kapila, S. (2015). Release of $\beta$ casomorphin-7/5 during simulated gastrointestinal digestion of milk $\beta$-casein variants from Indian crossbred cattle (Karan Fries). Food Chemistry, 168, 70-79.

https://doi.org/10.1016/j.foodchem.2014.07.024

Virtanen, S.M., Rasanen, L., Ylonen, K., Aro, A., Clayton, D., Langholz, B., Pitkäniemi, J., Savilahti, E., Lounamaa, R., Tuomilehto, J., Åkerblom, H.K. (1993). Early introduction of dairy products associated with increased risk of IDDM in Finnish children. The childhood in diabetes in Finland study group. Diabetes, 42(12), 1786-1790.

https://doi.org/10.2337/diab.42.12.1786

Virtanen, S.M. (2014). Hydrolyzed infant formula and early beta-cell autoimmunity: A randomized clinical trial. Journal of the American Medical Association, 311, 2279-2287.

https://doi.org/10.1001/jama.2014.5610

Wasilewska, J., Sienkiewicz-Szlapka, E., Kuźbida, E., Jarmołowska, B., Kaczmarski, M., Kostyra, E. (2011). The exogenous opioid peptides and DPPIV serum activity in infants with apnoea expressed as apparent life threatening events (ALTE). Neuropeptides, 45(3), 189-195.

https://doi.org/10.1016/j.npep.2011.01.005

Zeng, L., Mathew, A. V., Byun, J., Atkins, K.B., Brosius, F.C., Pennathur, S. (2018). Myeloperoxidase-derived oxidants damage artery wall proteins in an animal model of chronic kidney disease-accelerated atherosclerosis. Journal of Biological Chemistry, 293(19), 7238-7249.

https://doi.org/10.1074/jbc.RA117.000559

Zikakis, J.P., Haenlein, G.F., Hines, H.C., Mather, R.E., Tung, S. (1974). Gene frequencies of electrophoretically determined polymorphisms in Guernsey blood and milk. Journal of Dairy Science, 57(4), 405-410.

https://doi.org/10.3168/jds.S0022-0302(74)84904-0 